DOI: http://doi.org/10.21009/JKKP.081.06

\title{
KESEJAHTERAAN PSIKOLOGIS MAHASISWA YANG TELAH MENIKAH
}

\author{
Marlin Dubu ${ }^{1}$, Erly Oviane Malelak ${ }^{1^{*}}$, Yuvine Marlene Cicilia Noach ${ }^{1}$ \\ ${ }^{1}$ Institut Agama Kristen Negeri Kupang, Kupang 85112, Indonesia \\ *)E-mail: malelakerly@staknkupang.ac.id
}

\begin{abstract}
Abstrak
Kesejahteraan psikologis merupakan evaluasi seseorang tentang kehidupannya terkait penerimaan dirinya dalam sisi kehidupan yang positif maupun negatif sehingga mendapatkan kepuasan dan kebahagiaan. Mahasiswa yang sudah menikah kemudian berkuliah diperhadapkan dengan peran ganda baik sebagai suami/istri yang perlu menafkahi dan mengurus rumah tangga maupun sebagai mahasiswa dengan berbagai tuntutan akademik yang perlu diselesaikan. Hal ini menjadi tantangan baik dari pribadi mahasiswa sendiri maupun lingkungan eksternal. Penelitian ini bertujuan mengetahui kesejahteraan psikologis mahasiswa yang sudah menikah kemudian berkuliah. Metode penelitian yang digunakan ialah kualitatif. Subjek penelitian ditetapkan menggunakan purposive sampling, jumlah subjek 3 orang mahasiswa dengan kriteria berstatus menikah (menikah kemudian berkuliah), memiliki usia pernikahan di atas 5 tahun, rentang usia 20-50 tahun, dan merupakan mahasiswa jurusan Pastoral Konseling IAKN Kupang. Teknik pengumpulan data yang digunakan observasi dan wawancara. Instrumen penelitian yaitu pedoman wawancara dan observasi. Teknik analisis meliputi data reduction, data display dan conclusion drawing/verification. Hasil penelitian menunjukkan bahwa mahasiswa yang sudah menikah kemudian berkuliah di Jurusan Pastoral Konseling IAKN Kupang memiliki kesejahteraan psikologis yang baik dilihat dari aspek penerimaan diri, hubungan yang positif dengan sesama, otonomi, penguasaan lingkungan, tujuan hidup dan pertumbuhan pribadi.
\end{abstract}

Kata kunci: kesejahteraan psikologis, kuliah, mahasiswa, menikah

\section{The Psychological Well-Being of Married Students}

\begin{abstract}
Psychological well-being is an evaluation of a person about his life related to his acceptance of himself in the positive and negative sides of life so as to get satisfaction and happiness. Married students are then faced with a dual role, both as husband / wife who need to support and take care of the household as well as students with various academic demands that need to be resolved. This is a challenge both from the student's own person and the external environment. The purpose of this study was to determine the psychological well-being of students who were married and then went to university. The research method used is qualitative. The research subjects were determined using purposive sampling, the number of subjects was 3 students with the criteria of being married (married then studying), having a marriage age above 5 years, age range 20-50 years, and were students majoring in Pastoral Counseling IAKN Kupang. Data collection techniques used observation and interviews. The research instruments were interview and observation guidelines. Analysis techniques include data reduction, display data and conclusion drawing / verification. The results showed that married students who then studied at the Pastoral Counseling Department of IAKN Kupang had good psychological wellbeing in terms of self-acceptance, positive relationships with others, autonomy, environmental control, life goals and personal growth.
\end{abstract}

Keywords: married, psychological well-being, students, studying

\section{PENDAHULUAN}

Keluarga merupakan suatu unit terkecil dari sistem sosial masyarakat. Keluarga juga ikut berperan besar dalam menentukan kesejahteraan masyarakat. Selain itu, keluarga merupakan tempat yang penting bagi pertumbuhan dan perkembangan fisik dan psikis 
individu. Keluarga terdiri dari dua atau lebih individu yang terkait dengan darah, pernikahan atau adopsi. Sebuah keluarga yang ideal terdiri dari ayah, ibu dan anak-anak. Setiap anggota keluarga memiliki peran dan fungsi masing-masing guna membentuk suatu sistem keluarga yang harmonis.

Keluarga mempunyai fungsi sebagai penerus keturunan dan juga sumber pendidikan utama. Hal ini dikarenakan seluruh pengetahuan dan kecerdasan intelektual manusia diperoleh pertama-tama dari orangtua dan anggota keluarga sendiri (Gunarsa, 2011). Keluarga juga memiliki enam fungsi lainnya yang meliputi: 1) Pemecahan masalah yang terjadi di dalam keluarga, 2) Komunikasi, yakni informasi antar anggota keluarga dapat diketahui secara langsung dan kapan saja, 3) Peran keluarga mengacu pada pola perilaku yang ditetapkan oleh anggota keluarga untuk melengkapi keluarga fungsi, 4) Respons afektif mengacu pada tingkat respons emosional anggota keluarga terhadap rangsangan, 5) Keterlibatan afektif mengacu pada tingkat perhatian dan perhatian anggota keluarga terhadap berbagai kegiatan antar anggota keluarga, dan 6) Kontrol perilaku mengacu pada mode kontrol perilaku yang berbeda dalam situasi yang berbeda (Dai and Wang 2015).

Tugas keluarga pada umumnya sama, namun pemenuhan kebutuhan dilakukan dengan cara yang berbeda-beda sesuai peran dan fungsi tiap anggota keluarga agar tercapai suatu kesejahteraan. Seorang kepala keluarga, memiliki peran sebagai suami dan serta ayah bagi anak-anaknya. Seorang ibu rumah tangga juga memiliki peran sebagai istri dan ibu bagi anakanaknya (Bianca, 2014).

Terpenuhinya setiap peran dan fungsi dari masing-masing anggota keluarga juga akan mempengaruhi kondisi kesejahteraan psikologis dari masing-masing anggota keluarga itu sendiri. Berbagai hasil penelitian menggambarkan bahwa banyaknya gangguan perilaku dan psikologis memiliki keterkaitan dengan keluarga (Fan, Zhang, and Wang 2017). Kesejahteraan psikologis merupakan pencapaian penuh dari potensi psikologis seseorang dan suatu keadaan ketika individu dapat menerima kelebihan dan kekurangan diri, memiliki tujuan hidup, membangun relasi yang positif dengan orang lain, menjadi pribadi yang mandiri, mampu mengendalikan lingkungan, dan terus tumbuh secara personal (Ryff and Keyes 1995).

Kesejahteraan psikologis (psychological well-being) merupakan evaluasi seseorang tentang kehidupannya yang dapat menerima sisi kehidupan yang positif maupun negatif sehingga memiliki kepuasan dan kebahagiaan. Berdasarkan pada premis "being well" yang menunjukkan pada rentang karakteristik dan persepsi terhadap fungsi dari otonomi diri, penguasaan lingkungan, pertumbuhan pribadi, hubungan yang positif dengan orang lain, tujuan hidup dan penerimaan diri. Kesejahteraan erat hubungannya dengan terpenuhinya kebutuhan dasar individu yaitu kebutuhan yang berkaitan dengan having (memiliki), loving (mencintai), being (ada) dan health (kesehatan) (Susetyo, 2012). Kesejahteraan psikologis (psychological well-being) sebagai fungsi positif individu, di mana fungsi positif individu, merupakan arah atau tujuan yang diusahakan untuk dicapai oleh individu sehat (Ramadhani, Djunaedi, and Sismiati S. 2016).

Kesejahteraan psikologis mampu membuat seseorang dapat menerima diri apa adanya, membangun relasi yang baik dengan orang lain, mandiri dalam menghadapi tekanan sosial, mengendalikan lingkungan eksternal, memiliki arti hidup dan mampu mengaktualisasikan potensi diri (Prabowo, 2016). Kesejahteraan psikologis mampu membantu seseorang melalui tugas-tugas perkembangan, tenang dan mampu menyelesaikan berbagai permasalahan kehidupan. Namun, hal ini akan sulit dicapai oleh keluarga dengan orangtua yang memutuskan untuk menjalani proses perkuliahan dengan status sudah menikah (Ramadhani et al., 2016).

Mahasiswa yang sudah menikah kemudian berkuliah, selain diperhadapkan dengan peran baik sebagai seorang kepala keluarga (suami atau istri) yang bertanggung jawab untuk menafkahi keluarga atau seorang ibu rumah tangga yang bertanggung jawab mengurusi suami/istri, anak serta segala pekerjaan rumah, seringkali juga diperhadapkan dengan 
tanggung jawab sebagai seorang mahasiswa yang mempunyai banyak tuntutan tugas akademik seperti harus berkuliah dan juga menyelesaikan tugas kuliah. Hal inilah yang menjadi tantangan, masalah baik dari pribadi mahasiswa sendiri dan juga lingkungan eksternal.

Peran ganda yang dijalankan oleh suami/istri dapat menjadi penyebab stres dan mempengaruhi kesejahteraan psikologis seseorang (Pamintaningtiyas and Soetjiningsih 2020). Berbagai hasil penelitian menunjukkan bahwa ada hubungan antara peran ganda yang dijalankan atau work family conflict dengan kesejahteraan psikologis. Penelitian Anggarwati and Thamrin (2019) menunjukkan bahwa tingginya tingkat work family conflict pada ibu pekerja berdampak pada rendahnya tingkat kesejahteraan psikologis. Hasil penelitian senada juga diperoleh dari penelitian yang dilakukan Anwar \& Fauziah (2019) dan Pangastuti \& Sawitri (2015), yakni semakin tinggi kesejahteraan psikologis maka konflik peran ganda yang dialami rendah. Begitu juga sebaliknya, semakin rendah kesejahteraan psikologis maka konflik peran ganda yang dialami tinggi.

Seseorang yang bekerja, dan berkuliah tentunya tidak hanya diperhadapkan dengan work family conflict, tetapi juga diperhadapkan dengan peran lainnya yakni berkuliah. Adapun penelitian mengenai mahasiswa yang sudah menikah, terdapat beberapa hal yang secara signifikan berhubungan dengan kesiapan menikah, yaitu usia saat menikah, tingkat kedewasaan pasangan, waktu menikah, motivasi untuk menikah, kesiapan untuk sexual exclusiveness dan tingkat pendidikan serta aspirasi pekerjaan dan derajat pemenuhannya (Wisnuwardhani \& Sri, 2012). Hal ini dipertegas dengan penelitian sebelumnya yang dilakukan oleh (Anisaningtyas \& Astuti, 2011), didapatkan hasil bahwa adanya keinginan yang kuat dari dalam diri sehingga memacu seseorang untuk mewujudkan keinginan tersebut. Dalam hal ini keinginan responden adalah untuk menikah meskipun usia masih terbilang muda dan masih duduk di bangku kuliah. Keinginan responden untuk menikah didukung oleh perasaan yakin kepada calon suami dan juga yakin pada pernikahan yang akan dijalankan. Motivasi menikah di antaranya adalah takut akan dosa, menjaga agama, ingin membahagiakan orangtua, sudah merasa yakin dengan pasangan maupun keputusan menikah serta yakin bahwa dengan menikah adalah pilihan tepat bagi hidup. Di lain pihak, hal ini juga diharapkan mampu membantu responden dalam hal pembiayaan kuliah hingga selesai kuliah. Berdasarkan uraian di atas, maka permasalahan yang akan diteliti adalah bagaimana kesejahteraan psikologis mahasiswa yang sudah menikah.

\section{METODE}

Metode penelitian yang digunakan adalah kualitatif. Penelitian kualitatif dieksplorasi dan diperdalam dari suatu fenomena sosial atau suatu lingkungan sosial yang terdiri atas pelaku, kejadian, tempat dan waktu (Komariah \& Satori 2012).

Subjek penelitian ditetapkan dengan menggunakan purposive sampling dengan mengkhususkan pada subjek yang sesuai dengan tujuan penelitian. Jumlah subjek sebanyak 3 orang mahasiswa, dengan kriteria subjek yaitu berstatus menikah (menikah kemudian berkuliah) yang memiliki usia pernikahan di atas 5 tahun dengan rentang usia 20-50 tahun, dan merupakan mahasiswa jurusan Pastoral Konseling IAKN Kupang.

Teknik pengumpulan data yang digunakan yaitu observasi dan wawancara. Instrumen penelitian ini adalah peneliti sendiri. Peneliti menyiapkan pedoman wawancara dan observasi yang berisi pertanyaan-pertanyaan yang sesuai dengan pokok permasalahan dalam penelitian. Pokok permasalahan ini dapat berkembang sehingga peneliti menemukan informasi lain yang berhubungan dengan pokok permasalahan tersebut selama wawancara berlangsung (Alsa, 2014). Oleh karena itu instrumen dalam penelitian ini adalah peneliti sendiri, pedoman wawancara dan observasi. Pedoman ini disusun berdasarkan 6 (enam) Dimensi Kesejahteraan Psikologi berdasarkan teori Riff yakni penerimaan diri (self 
acceptance), hubungan yang positif dengan sesama (positive relation with other), otonomi (autonomy), penguasaan lingkungan (environmental mastery), tujuan hidup (purpose in life), dan pertumbuhan pribadi (personal growth).

Analisis data dalam penelitian ini meliputi data reduction, data display dan conclusion drawing/verification. Miles \& Huberman mengemukakan bahwa aktifitas dalam analisis data kualitatif dilakukan secara interaktif dan berlangsung secara terus menerus sampai tuntas, sehingga memperoleh data jenuh (Sugiyono, 2018).

\section{HASIL DAN PEMBAHASAN}

\section{A. Hasil}

Hasil penelitian ini menunjukkan gambaran kesejahteraan psikologis Mahasiswa yang telah menikah. Menurut Ryff (1989), ada 6 dimensi kesejahteraan psikologis yaitu: penerimaan diri (self-acceptance), relasi yang baik dengan orang lain (positive relations with others), otonomi/kemandirian (autonomy), penguasaan lingkungan (environmental mastery), tujuan dalam hidup (purpose in life) dan pertumbuhan diri (personal growth). Berdasarkan analisis hasil penelitian diketahui bahwa pada setiap subjek muncul masalah yang berbeda-beda bila dilihat dari setiap aspek kesejahteraan psikologis.

\section{Subjek I (S1)}

\section{a. Penerimaan Diri (Self Acceptance)}

Berdasarkan wawancara yang terhadap $\mathrm{S} 1$, diperoleh data yang menunjukkan penerimaan diri subjek, dimana pada saat menjalani kehidupan ketika belum berkuliah dan setelah berkuliah sangat jauh berbeda. Ketika belum berkuliah dengan status sudah menikah subjek hanya memfokuskan seluruh perhatian pada keluarga seperti mengurus rumah tangga, menyelesaikan pekerjaan rumah, mengurus anak dan suami serta keluarga tetapi setelah memutuskan untuk berkuliah, subjek tidak hanya memfokuskan pikiran serta perasaan untuk keluarga namun juga harus memikirkan tugas kuliah dan mengikuti perkuliahan. Pada awal memutuskan untuk berkuliah subjek sempat merasakan cemas, stres, gelisah dan tertekan karena memikirkan bagaimana cara mengatur waktu untuk menjalankan peran menjadi mahasiswa dan ibu rumah tangga dengan baik tanpa harus mengorbankan salah satu peran.

Namun, tidak bisa dipungkiri bahwa subjek sempat menemui kendala dalam mengatur waktu dan menjalankan peran sebagai ibu rumah tangga. Kendala tersebut seperti anak atau anggota keluarga ada yang sakit, waktu kuliah yang berbenturan dengan acara keluarga, mengurus rumah tangga bahkan subjek sering sakit-sakitan (gejala asma) sangat benar-benar memberikan pengaruh bagi subjek. Kendala tersebut menimbulkan kecemasan, gelisah, stres, tetapi sempat mengalami tekanan batin akibat rasa bersalah karena tidak dapat memfokuskan perhatiannya seperti dulu kepada keluarga. Subjek juga merasa kasihan ketika melihat anak-anak dan suami hingga turun tangan untuk membantu menyelesaikan pekerjaan rumah yang ada.

Seiring berjalannya waktu karena mendapatkan dukungan penuh dari suami, anak dan keluarga untuk berkuliah maka subjek memutuskan untuk menerima keadaan diri saat ini dimana subjek berusaha untuk tetap memainkan peran sebagai ibu rumah tangga walaupun tidak terlepas dari bantuan suami, anak dan keluarga untuk menjalankan perannya dengan baik.

b. Hubungan yang positif dengan sesama (Positive Relation with Other)

Subjek dapat membangun dan memiliki hubungan yang positif dengan sesama seperti suami, anak-anak, keluarga, tetangga, teman-teman mahasiswa, bapak/ ibu 
dosen maupun siapa saja. Hal ini dikarenakan adanya dukungan, pengertian dan semangat yang penuh kepada subjek dalam memberikan keputusan untuk berkuliah serta menjalani tugas dan tanggungjawab sebagai seorang ibu rumah tangga maupun sebagai mahasiswa.

Hubungan positif dengan sesama meliputi pemberian bantuan dari anak-anak dalam menyelesaikan pekerjaan di rumah; antar anggota keluarga sering bercerita tentang situasi di kampus serta pencapaian proses pembelajaran di kampus, melakukan rekreasi di hari libur bersama anggota keluarga, bermain dan membantu anak-anak menyelesaikan menyelesaikan tugas sekolah, makan bersama keluarga, mengunjungi orangtua, saling menyapa tetangga, saling menolong atau memberikan bantuan bagi tetangga, dan saling memberikan pengertian, semangat, dukungan untuk tetap mengerjakan tugas serta rajin untuk berkuliah di antara sesama teman kuliah.

\section{c. Otonomi (Autonomy)}

Subjek mampu untuk memberikan keputusan sendiri, mandiri serta dapat mengatur perilaku dan sikapnya sendiri. Hal ini terlihat dari keterlibatan subjek dalam mengurus rumah tangga sendiri tanpa bantuan asisten rumah tangga, menyelesaikan tugas perkuliahan sendiri, serta sering memberikan bantuan bagi teman-teman mahasiswa lainnya yang kesulitan mengerjakan tugas.

Ketika awal berkuliah dengan status sudah menikah terdapat banyak perasaan dan pikiran negatif yang membuat subjek mengalami kendala mulia dari mengurus suami dan anak-anak, dirinya sendiri hingga waktu untuk berkuliah dan mengerjakan tugas. Namun hambatan-hambatan tersebut dapat diatasi ketika subjek membangun hubungan yang lebih intens dengan Tuhan dengan berdoa.

\section{d. Penguasaan lingkungan (Environmental Mastery)}

Subjek mampu untuk memilih kondisi dan lingkungan yang kondusif serta melibatkan diri dalam beberapa kegiatan dilingkungan tempat tinggalnya seperti mengikuti kegiatan kampus (kegiatan jurusan), menjadi guru/pengajar sekolah minggu, terlibat dalam ibadat rumah tangga, wanita GMIT, dan kegiatan lainnya bersama tetangga. Subjek sering tertekan dalam membagi waktunya sehingga subjek memutuskan untuk tidak terlalu menyibukkan diri dengan berbagai kegiatan di luar rumah seperti mengikuti organisasi kampus dan kegiatan-kegiatan lainnya yang terlalu menyita waktu subjek.

e. Tujuan hidup (Purpose in life)

Subjek mampu menemukan makna hidup di masa lalu hingga saat ini, dimana pada masa yang lalu terjadi banyak peristiwa yang dialami subjek tetapi akhirnya subjek mampu menentukan arah dan tujuan hidupnya ke depan. Tujuan hidup subjek ialah menjadi sama seperti ibunya yaitu menjadi wanita karier dengan pekerjaan yang mapan.

\section{f. Pertumbuhan pribadi (Personal Growth)}

Subjek memiliki potensi dalam diri yaitu pandai berdansa atau menari. Subjek mengembangkan potensi dirinya untuk berkembang serta bertumbuh dengan baik. Namun, seiring berjalannya waktu setelah memutuskan untuk menikah, subjek tidak lagi melanjutkan dan mengembangkan potensi yang ada tetapi lebih memilih untuk berhenti menekuni hobinya tersebut lantaran subjek berkeinginan untuk memfokuskan diri menjadi ibu rumah tangga yang benar-benar mau mengurus suami, anak-anak dan keluarga. Subjek hanya menekuni potensi dirinya sebagai seorang pengajar sekolah minggu yang pada setiap minggunya melayani anak-anak sekolah minggu. 


\section{Subjek II (S2)}

\section{a. Penerimaan diri (Self Acceptence)}

Berdasarkan wawancara kepada S2, ditemukan adanya sikap penerimaan diri. Sikap penerimaan diri ini nampak pada awal subjek memutuskan untuk berkuliah dengan status sudah menikah tentu muncul berbagai perasaan dan pikiran seperti stres, tertekan, cemas dan gelisah untuk menghadapi setiap situasi yang akan terjadi dan dialami subjek ketika telah berkuliah. Namun, seiring berjalannya waktu subjek mulai memutuskan perlu menerima diri dan kenyataan bahwa ia harus menjalani peran baik sebagai ibu rumah dan juga seorang mahasiswa. Subjek berusaha untuk tetap menguatkan hati agar dapat menjalani semua ini dengan sebaik mungkin.

b. Hubungan yang positif dengan sesama (Positive Relation with Other)

Subjek dapat membangun dan memiliki hubungan yang positif dengan sesama kepada suami, anak, keluarga, tetangga, teman-teman mahasiswa dan bapak dan ibu dosen. Hal ini dikarenakan adanya dukungan dan semangat kepada subjek untuk berkuliah.

c. Otonomi (Autonomy)

Subjek memiliki otonomi, hal ini ditandai dengan keputusan yang diambil subjek untuk berkuliah dan didukung oleh keluarga. Namun, dalam menjalankan perannya subjek selalu dibantu oleh suami dalam menyelesaikan pekerjaan rumah serta ibu yang membantu subjek dalam mengasuh anak agar subjek dapat berkuliah dan menyelesaikan tugas kuliah. Subjek juga sering mengerjakan tugas kuliah sendiri maupun berkelompok sampai selesai dan mendapatkan nilai yang baik.

d. Penguasaan lingkungan (Environmental Mastery)

Subjek tidak terlalu melibatkan diri dalam kegiatan di lingkungannya baik di lingkungan tempat tinggal maupun lingkungan kampus karena sibuk mengikuti perkuliahan dan hanya ingin berkuliah secara baik tanpa terlalu sibuk dengan berbagai kegiatan.

e. Tujuan hidup (Purpose in life)

Subjek mampu untuk memaknai kehidupan yang dijalaninya baik masa lalu maupun masa sekarang serta mampu menentukan arah dan tujuan hidup dimasa depan. Subjek memiliki harapan agar kedepannya untuk menjadi pribadi yang lebih dewasa dan menjadi lebih baik lagi, mampu membahagiakan keluarga terutama suami dan ibu yang setia memberikan kasih sayang kepadanya dan mengurusnya seorang diri tanpa sosok seorang ayah, serta menjadi guru seperti ibunya.

f. Pertumbuhan pribadi (Personal Growth)

Subjek memiliki potensi menjahit, namun potensi tersebut tidak lagi dikembangkan semenjak dirinya sibuk dengan berkuliah karena keterbatasan waktu yang dimiliki. Sebelumnya berkuliah subjek sangat tidak percaya diri dan tidak berani berbicara di depan banyak orang. Namun, seiring sejak mulai berkuliah subjek mengalami perubahan karena harus menyesuaikan dengan keadaan di lingkungan perkuliahan.

\section{Subjek III (S3)}

\section{a. Penerimaan diri (Self Acceptence)}

Berdasarkan wawancara terhadap S3 ditemukan adanya penerimaan diri, dimana pada awal subjek memutuskan untuk berkuliah dengan status sudah menikah dan bekerja tentu membuat subjek merasakan perasaan yang sangat tidak menyenangkan 
seperti gelisah, tertekan, cemas bahkan bingung bagaimana menjalani semua ini dengan baik. Subjek sempat merasa sangat kesulitan dalam membagi peran yang ada. Setelah memutuskan untuk berkuliah sampai dengan saat ini, subjek memainkan peran baik sebagai orangtua, aparat penegak hukum (polisi), pengajar sekolah minggu, majelis/presbiter dan juga sebagai seorang mahasiswa.

Dalam perjalanan subjek mulai memutuskan untuk menguatkan dirinya, namun dalam proses tersebut subjek merasa sulit membagi waktu untuk bekerja karena sebagai salah satu aparat penegak hukum (polisi) tentu memiliki tugas dan tanggungjawab yang besar.

b. Hubungan yang positif dengan sesama (Positive Relation with Other).

Subjek memiliki kemampuan untuk membina hubungan yang positif dengan sesama. Hal tersebut digambarkan dengan hubungan baik dan hangat yang dibangun subjek dengan anak-anak, istri, orang tua, tetangga, teman-teman di kampus, dan di tempat kerja.

c. Otonomi (Autonomy)

Subjek mampu mengambil keputusan, mandiri dalam mengerjakan tugas-tugas kuliah, mampu mengatur perilaku dan sikapnya, serta menafkahi keluarganya. Sejak memutuskan untuk berkuliah, semakin banyak pula tangungjawab yang diemban apalagi subjek juga merupakan seorang yang menerima tanggungjawab di gereja sebagai pengajar dan juga majelis/presbiter yang harus melayani jemaat.

\section{d. Penguasaan lingkungan (Environmental Mastery)}

Subjek memiliki kemampuan untuk memilih situasi dan lingkungan yang kondusif serta mampu melibatkan diri dalam kegiatan di lingkungannya baik lingkungan tempat kerja, tempat tinggal, gereja maupun kampus. Subjek terlibat dalam kegiatan di tempat kerja, di lingkungan tempat tinggal seperti beribadah di gereja bersama keluarga, mengikuti ibadat rumah tangga, ibadah Kaum Bapak, dan mengajar sekolah minggu serta subjek juga terlibat dalam kegiatan di kampus seperti pelayanan dan pengabdian pada masyarakat, ibadat bersama setiap Senin dan Jumat serta mengikuti organisasi kampus yaitu sebagai anggota Badan Eksekutif Mahasiswa (BEM).

e. Tujuan hidup (Purpose in life)

Subjek mampu untuk menemukan makna hidup serta mampu menentukan arah dan tujuan hidup yang lebih baik. Tujuan hidup subjek terkait kuliah yaitu mempelajari ilmu konseling untuk membantu pekerjaannya sebagai seorang polisi, majelis/pengajar dan juga seorang ayah yang baik. Subjek memiliki harapan untuk terus melayani Tuhan dan menjadi yang terbaik bagi keluarganya terutama menjadi sosok ayah yang dapat membimbing, mengasuh dan mendidik anak-anak dengan baik.

f. Pertumbuhan pribadi (Personal Growth)

Subjek mampu mengembangkan potensi diri untuk bertumbuh secara efektif dari waktu ke waktu. Subjek memiliki potensi dalam menegakkan keadilan dengan cara tetap mengatakan salah jika salah dan mengatakan benar jika memang itu benar. Hal tersebut mulai nampak ketika subjek masih duduk dibangku SMK. Subjek merasa mendapatkan kepuasan ketika keadilan dapat ditegakkan, oleh karena itu hal ini juga terus dipertahankan hingga subjek menjadi seorang aparat penegak hukum/ polisi. Selain itu, subjek juga semakin mengembangkan diri untuk terus melayani di gereja maupun di kampus. 


\section{B. Pembahasan}

Kesejahteraan psikologis berasal dari perspektif perkembangan masa hidup manusia, yang menekankan berbagai tantangan yang dihadapi pada berbagai fase dalam silkus hidup yang di hadapi oleh manusia. Kesejhteraan psikologis juga didefinisikan sebagai sebuah kondisi dimana kehidupan manusia berjalan dengan baik sebagai hasil kombinasi dari perasaan-perasaan dan berfungsi secara efektif (Kurniasari et al., 2019). Kesejahteraan psikologis dapat diukur melaui dimensi-dimensi yang ada. Terdapat enam dimensi kesejahteraan psikologis (Budisetyani, dkk 2018). Keenam dimensi tersebut meliputi:

a. Penerimaan diri (Self Acceptence). Penerimaan diri merupakan perasaan positif terhadap diri sendiri termasuk masa lalu, dapat menentukan sikap atas kemauan diri sendiri, yang dibarengi dengan adanya penerimaan terhadap seluruh kelebihan serta kelemahan yang dimiliki.

b. Hubungan yang positif dengan sesama (Positive Relation with Other). Hubungan positif dengan sesame ditandai dengan kemampuan menunjukkan kehangatan, kepercayaan dalam menjalin hubungan sosial, mampu berempati, kepedulian terhadap sesama serta mampu memahami hubungan yang saling memberi dan menerima secara interpersonal.

c. Otonomi (Autonomy). Otonomi merupakan kemampuan untuk berpikir dan berperilaku secara tepat ketika berada dalam tekanan, adanya keputusan yang ditentukan atas diri sendiri, serta adanya evaluasi diri yang didasarkan pada standar pribadi.

d. Penguasaan lingkungan (Environmental Mastery). Penguasaan lingkungan adalah kemampuan menggunakan kesempatan yang ada di lingkungan sekitar secara efektif, serta mampu untuk memilih dan membuat suatu kondisi sesuai dengan nilai dan apa yang dibutuhkan oleh diri sendiri.

e. Tujuan hidup (Purpose in Life). Tujuan hidup diartikan sebagai adanya perasaan penuh arti yang dimiliki individu mengenai masa lalu dan kehidupan saat ini, memiliki arti dan tujuan yang tinggi dalam hidup serta ingin menjalankan hidup lebih terarah.

f. Pertumbuhan pribadi (Personal Growth). Pertumbuhan pribadi mengarah pada adanya keterbukaan terhadap pangalaman-pengalaman baru, perasaan mengenai perkembangan dan pertumbuhan diri sendiri yang berkelanjutan, adanya refleksi dari pengetahuan, keterampilan, dan talenta yang telah ada, serta adanya perasaan atau keinginan untuk mewujudkan potensi diri yang dimiliki.

Setiap subjek membutuhkan waktu yang tidak terlalu berbeda jauh untuk melakukan penerimaan diri serta menyesuaikan dengan kondisi dan keadaan yang dijalani. Informasi mengenai rentang waktu dan peran dari masing-masing subjek yang berpengaruh terhadap kesejahteraan psikologisnya disajikan pada Tabel 1.

Tabel 1. Rentang waktu penerimaan diri mahasiswa yang sudah menikah kemudian berkuliah

\begin{tabular}{|c|c|c|c|}
\hline Subjek & $\begin{array}{l}\text { Rentang waktu } \\
\text { penerimaan diri }\end{array}$ & Peran yang dijalani & Faktor yang mendukung \\
\hline I & $\begin{array}{l}\text { Usia } 33 \text { tahun: } \\
\text { berkuliah selama } 1 \\
\text { tahun dan membutuhkan } \\
\text { waktu } 3 \text { bulan untuk } \\
\text { menerima diri }\end{array}$ & $\begin{array}{l}\text { 1. Ibu Rumah } \\
\text { Tangga/ istri } \\
\text { 2. Mahasiswa }\end{array}$ & $\begin{array}{l}\text { 1. Suami dan anak-anak } \\
\text { 2. Keluarga } \\
\text { 3. Lingkungan }\end{array}$ \\
\hline
\end{tabular}




\begin{tabular}{|c|c|c|c|}
\hline Subjek & $\begin{array}{l}\text { Rentang waktu } \\
\text { penerimaan diri }\end{array}$ & Peran yang dijalani & Faktor yang mendukung \\
\hline II & $\begin{array}{l}\text { Usia } 26 \text { tahun: } \\
\text { berkuliah selama } 3 \text { tahun o } \\
\text { membutuhkan waktu } 4 \text { buli } 2 \\
\text { untuk menerima diri }\end{array}$ & $\begin{array}{l}\text { 1. Ibu Rumah } \\
\text { Tangga/ istri } \\
\text { 2. Mahasiswa }\end{array}$ & $\begin{array}{l}\text { 1. Suami dan anak } \\
\text { 2. Keluarga } \\
\text { 3. Lingkungan }\end{array}$ \\
\hline III & $\begin{array}{l}\text { Usia } 40 \text { tahun: } \\
\text { berkuliah selama } 2 \text { tahun c } \\
\text { membutuhkan waktu } 2 \text { buli } 2 \\
\text { untuk menerima diri }\end{array}$ & $\begin{array}{l}\text { 1. Kepala Keluarga/ } \\
\text { ayah/ suami } \\
\text { 2. Polisi } \\
\text { 3. Mahasiswa }\end{array}$ & $\begin{array}{l}\text { 1. Istri dan anak-anak } \\
\text { 2. Keluarga } \\
\text { 3. Instansi } \\
\text { (Polda NTT) } \\
\text { 4. Gereja }\end{array}$ \\
\hline
\end{tabular}

Berdasarkan hasil penelitian terhadap ketiga subjek, diketahui bahwa dibutuhkan rentang waktu yang berbeda-beda untuk dapat melakukan penerimaan diri oleh masingmasing subjek. S1 membutuhkan waktu 3 bulan, S2 membutuhkan waktu 4 bulan, dan S3 membutuhkan waktu 2 tahun untuk melakukan penerimaan diri dengan peran yang dijalankan setelah berkuliah. Perbedaan waktu penerimaan diri ini dipengaruhi oleh berbagai faktor seperti, pengalaman di masa lalu, perilaku dalam memecahkan permasalahan, keyakinan diri, dan reaksi emosi (White, 2012).

Ketiga subjek dapat menerima diri untuk menjalankan peran secara penuh karena adanya faktor internal dan eksternal berupa dorongan dari dalam diri dan juga dukungan sosial dari berbagai pihak. Faktor internal dan eksternal ini dijabarkan Hurlock ke dalam sepuluh faktor (Ardilla \& Herdiana, 2013). Dukungan sosial yang didapatkan mampu membuat ketiga subjek memainkan peran mereka baik sebagai orang tua maupun sebagai mahasiswa dengan baik. Hal ini ditunjukkan dengan adanya perhatian, bantuan/pertolongan yang diberikan dari berbagai pihak kepada ketiga subjek sehingga dapat tetap mengurus rumah tangga, mengerjakan pekerjaan rumah, berkuliah, mengerjakan tugas kuliah dan memperoleh pencapaian hasil belajar yang baik.

Terdapat proses yang dilalui untuk mencapai penerimaan diri. Diawali dengan berbagai situasi psikologis yang negatif seperti tertekan, stres, cemas, bingung dan gelisah akan peran ganda yang dijalani. Namun adanya dorongan dari faktor internal dan eksternal membuat proses tersebut dapat dilalaui dengan baik, sehingga tercapai penerimaan diri.

Penelitian menunjukkan bahwa ketiga subjek sama dalam hal kemandirian namun berbeda dalam proses menjalani peran. S1 dan S3 sama-sama merupakan orang tua yang dapat menjalani peran secara penuh. Artinya, disamping menyelesaikan tugas kampus dan menjadi seorang mahasiswa juga dapat mengurus rumah, anak-anak dan pekerjaan rumah tangga lainnya. Sedangkan S2, menjalani peran sebagai mahasiswa dan orang tua namun tidak sepenuhnya dapat mengurus anak karena anak subjek ditinggalkan bersama ibu dari S2. Disamping itu ketiga subjek sama-sama mandiri dalam hal membayar uang kuliah sendiri dengan cara masing-masing suami bekerja dan membantu pembayaran SPP kuliah.

Dalam hal penguasaan lingkungan, semua subjek memberi respon yang positif. Penguasaan lingkungan yang baik merupakan salah satu aspek kesejahteraan psikologis. Individu dengan kesejahteraan psikologis yang baik akan memiliki interaksi yang baik serta mampu melibatkan diri dalam setiap aktivitas di lingkungannya. Kesejahteran psikologis meliputi keterikatan aktif dalam dunia dan hubungan seseorang dalam objek ataupun orang lain (Ramadhani et al., 2016). Penguasaan lingkungan juga memainkan peran sentral dalam kesejahteraan psikologis individu yang memiliki peran ganda (Meriko \& Hadiwirawan., 2019). 
Selain itu, individu mampu mengontrol lingkungannya sesuai dengan kondisi psikologisnya dan mampu memanfaatkan kesempatan yang ada dilingkungan secara efektif (Rahmawati, 2017).

Ketiga subjek memiliki tujuan hidup yang terarah dan baik. Individu yang memiliki tujuan hidup adalah individu yang mempunyai kesadaran yang tinggi akan tujuan, mensyukuri hidup serta mengambil makna dari hidup yang dijalani. Adanya tujuan hidup menandakan adanya kesejahteraan psikologis seseorang. Tujuan hidup ketiga subjek memiliki keterkaitan dengan tingkat religiusitas yang dimiliki. Mendukung hal ini, ketiga subjek memiliki tingkat religiusitas yang baik, terlihat dari keaktifan mereka dalam aktivitas keagamaan, adanya rasa syukur dan usaha untuk mendekatkan diri dengan Tuhan. Semakin dekat seseorang terhadap penciptanya akan menumbuhkan rasa syukur dan mengurangi stres yang berkepanjangan (Aprilia, 2013).

Dalam hal potensi, S1 dan S2 masing-masing memiliki potensi namun tidak dikembangkan lagi, sedangkan S3 berusaha mengembangkan potensinya melalui pekerjaannya saat ini. Jadi ditemukan perbedaan dari tiap subjek dalam mempertahankan dan mengembangkan potensi yang dimiliki.

Status ekonomi juga memiliki pengaruh terhadap kesejahteraan psikologis mahasiswa yang sudah menikah kemudian berkuliah. Semakin baik keadaan ekonomi dalam keluarga maka dapat memenuhi semua kebutuhan hidup termasuk membiayai perkuliahan. S1 dan S2 mempunyai suami yang bekerja dan S3 sudah memiliki pekerjaan sendiri. Bertolak dari hasil penelitian yang dilakukan terhadap ketiga orang subjek, maka dapat juga dilihat adanya dukungan sosial yang membuat ketiga subjek merasa diperhatikan, dicintai, dihargai dan dihormati sehingga mampu mendorong ketiga subjek untuk berkarya dengan peran mereka masing-masing. Hal ini senada dengan pendapat Sarafino bahwa dukungan sosial sebagai perasaan nyaman, penghargaan, perhatian, atau bantuan yang diperoleh seseorang dari orang lain atau kelompoknya (Aprilia, 2013).

Mahasiswa yang berstatus menikah kemudian berkuliah diperhadapkan dengan peran ganda, yakni menjadi kepala keluarga/ibu rumah tangga dengan berbagai perasaan seperti cemas, tertekan, stres, sedih, rasa bersalah dan sebagainya namun hal tersebut berhasil dilewati dengan baik oleh masing-masing subjek karena mendapatkan dukungan penuh dari berbagai pihak di antaranya keluarga, lingkungan tempat tinggal, gereja dan instansi terkait. Dukungan-dukungan ini membantu subjek dalam menjalani peran gandanya dengan baik, sehingga meminimalisir timbulnya konflik peran ganda. Hasil penelitian ini sejalan oleh penelitian terdahulu terkait dukungan dari keluarga dan rekan kerja dalam menjalankan peran ganda (O'Driscoll et al., 2004). Dengan demikian, dapat disimpulkan bahwa ketiga subjek dalam penelitian ini memiliki kesejateraan psikologis yang baik meskipun diperhadapkan dengan peran ganda sebagai suami/istri, pekerja dan mahasiswa.

\section{SIMPULAN DAN SARAN}

Hasil penelitian menunjukkan bahwa mahasiswa yang sudah menikah kemudian berkuliah di Jurusan Pastoral Konseling IAKN Kupang memiliki kesejahteraan psikologis yang baik. Pada awal memutuskan untuk berkuliah dengan status menikah, tentu membuat ketiga subjek merasa minder atau kurang percaya diri dikarenakan memiliki usia dan status yang berbeda dengan mahasiswa lainnya. Ketiga subjek juga sempat merasakan tertekan, stres, rasa bersalah, bingung dan cemas akan menjalani semua peran yang ada. Semua hal tersebut tentu membuat ketiga subjek awalnya sulit menerima diri dengan kenyataan yang ada untuk bagaimana harus menghadapinya. Namun, seiring berjalannya waktu ketiga subjek dapat menerima diri secara penuh karena adanya dukungan serta dorongan dari dalam diri dan juga dukungan dari keluarga, lingkungan sekitar, gereja dan instansi terkait sehingga ketiga subjek memutuskan untuk terus menghadapi semuanya dengan semangat dan selalu optimis 
walaupun banyak tugas dan tanggung jawab yang menanti seperti menjadi ibu rumah tangga/kepala keluarga, aparat penegak hukum (polisi) dan juga menjadi seorang pengajar/majelis. Ketiga subjek juga merasa puas dengan kehidupan yang saat ini mereka jalani.

Saran yang dapat diberikan ialah: 1) Mahasiswa yang menikah kemudian berkuliah. Bagi seorang mahasiswa yang sudah menikah kemudian berkuliah agar dapat lebih menerima diri dan kehidupannya saat ini serta dapat menyesuaikan diri dengan baik tanpa melihat status agar tidak minder/kurang percaya diri, karena pada dasarnya semua orang berhak untuk belajar dan melanjutkan studi, menggapai impian dan mewujudkan keinginan tanpa dibatasi ruang, waktu dan status; 2) Keluarga. Suami/istri, anak-anak dan juga keluarga diharapkan agar terus memberikan dukungan dan dorongan kepada mahasiswa yang sudah menikah kemudian berkuliah sehingga tetap semangat menjalani hari-hari mereka kedepannya. Keluarga perlu memberikan perhatian dan juga menghargai setiap usaha yang telah dilakukan; dan 3) Peneliti selanjutnya. Diharapkan agar dapat mencari dan menggali informasi lebih dalam lagi agar memperoleh hasil yang lebih mendalam dan berbeda dari penelitian sebelumnya.

\section{DAFTAR PUSTAKA}

Alsa, A. (2014). Pendekatan Kuantitatif dan Kualitatif Serta Kombinasi dalam Penelitian Psikologi. Pustaka Pelajar.

Anggarwati, P., \& Thamrin, W. (2019). Work family-conflict dan psychological well-being pada ibu bekerja. Jurnal Psikologi, 200-212. https://doi.org/10.35760/psi.2019.v12i2.2444.

Anisaningtyas, G., \& Astuti, Y.D. (2011). Pernikahan di kalangan mahasiswa S-1. Jurnal Psikologi Proyeksi, 6(2), 21-33. https://doi.org/10.30659/p.6.2.21-33.

Anwar, D. P., \& Fauziah, N. (2019). Hubungan Antara Kesejahteraan Psikologis Dengan Konflik Peran Ganda Pada Wanita Yang Bekerja Sebagai Polisi Di Polrestabes Semarang. Empati, 8(1), 105-110.

Aprilia, W. (2013). Resiliensi Dan Dukungan Sosial Pada Orang Tua Tunggal (Studi Kasus pada Ibu Tunggal di Samarinda). Psikoborneo Jurnal IImiah Psikologi, 1(3), 157-163.

Ardilla, F., \& Herdiana, I. (2013). Penerimaan Diri pada Narapidana Wanita. Jurnal Psikologi Kepribadian dan sosial. Vol. 2(1).

Bianca, R. (2014). Konstruksi Sosial Singel Mother di Surabaya (Studi Deskriptif tentang Singel Mother Berusia Produktif yang Mempertahankan Statusnya Sebagai Orangtua Tunggal). Jurnal Sosiologi Departemen Sosiologi, (4), 1-2.

Brewer, M. B., \& Pierce, K. P. (2005). Social identity complexity and outgroup tolerance. Personality and Social Psychology Bulletin, 31, 428-437.

Budisetya, dkk. (2018). Psikologi Positif dalam Perkembangan Manusia. Denpasar: Udayana University Press

Dai, L., \& Wang, L. (2015). Review of Family Functioning. Open Journal of Social Sciences, 3(12), 134-141. https://doi.org/10.4236/jss.2015.312014.

Fan, H., Zhang, B., \& Wang, W. (2017). Family Functions in Relation to Behavioral and Psychological Disorders in Chinese Culture. The Family Journal. https://doi.org/10.1177/1066480717697681.

Gunarsa, D. S. \& Singgih, Y. D. G. (2004). Psikologi Praktis: Anak, Remaja dan Keluarga. PT Gunung Mulia. 
Hyde, J., Hankins, M., Deale. A., \& Marteau, T. M. (2008). Interventions to increase selfefficacy in the context of addiction behaviours: A systematic literature review. Journal of Health Psychology, 13(5), 607-623.

Komariah, A. \& Satori, D. (2012). Metodologi Penelitian Kualitatif. Bandung: Alfabeta.

Kurniasari, E, Rusmana, N., \& Budiman, N. (2019). Gambaran Umum Kesejahteraan Psikologis Mahasiswa. Journal of Innovative Counseling: Theory, Practice, and Research, 3(2), 52-58. https://doi.org/10.1177/1069072717714538.

Meriko, Cito, \& Hadiwirawan, O. (2019). Kesejahteraan Psikologis Perempuan Yang Berperan Ganda. SEURUNE: Jurnal Psikologi Unsyiah, 2(1), 68-99. https://doi.org/10.24815/sjpu.v2i1.13273.

Mike P. O'Driscoll, P. Mike., Brough, Paula., \& Kalliath, J. Thomas. (2004). Work/Family Conflict, Psychological Well-Being, Satisfaction and Social Support: A Longitudinal Study in New Zealand. Equal Opportunities International, 23(1/2). DOI: 10.1108/02610150410787846

Pamintaningtiyas, Dimarda, I, \& Soetjiningsih, C. H. (2020). Hubungan antara work family conflict dengan psychological well-being pada ibu yang bekerja sebagai perawat di rumah sakit sumber kasih Cirebon. Psikologi Konseling. https://doi.org/10.24114/konseling.v16i1.19142.

Pangastuti, Bening, and Sawitri, D. R. (2015). Hubungan Antara Konflik Peran PekerjaanKeluarga Kowad di Kodam IV/Diponegoro. Jurnal Empati, 4(2), 203-8.

Ramadhani, T., Djunaedi, \& Sismiati, A. (2016). Kesejahteraan psikologis (psychological wellbeing) siswa yang orangtuanya bercerai (Studi Deskriptif yang dilakukan pada Siswa di SMK Negeri 26 Pembangunan Jakarta). Insight: Jurnal Bimbingan Konseling, 5(1), 108115. https://doi.org/10.21009/insight.051.16.

Ryff, C. D., \& Keyes, C. L. (1995). The Structure of Psychological Well-Being Revisited. Journal of Personality and Social Psychology, 69(4), 719-727. https://doi.org/10.1037/00223514.69.4.719.

Sugiyono. (2014). Metode Penelitian kuantitaf, kualitatif dan R\&D. Alfabeta.

White, B. (2011). Why Self Acceptance Is So Powerful. Bloomington: iUniverse.

Wisnuwardhani \& Sri. (2012). Fenomena Mahasiswa Menikah Sebelum Menyelesaikan Kuliah. Jurnal Psikologi, 55. 